\title{
Review
}

\section{Novel Diagnosis of Lyme Disease: Potential for CAM Intervention}

\author{
Aristo Vojdani ${ }^{1}$, Frank Hebroni ${ }^{2}$, Yaniv Raphael ${ }^{3}$, Jonathan Erde $^{4}$ and Bernard Raxlen ${ }^{5}$ \\ ${ }^{1}$ Immunosciences Laboratory, Inc., Beverly Hills, CA 90211, ${ }^{2}$ Department of Psychobiology, University of \\ California, ${ }^{3}$ Department of Biology, University of Southern California, ${ }^{4}$ Department of Biochemistry, \\ University of California and ${ }^{5}$ Raxlen Clinic, New York, NY 10024, USA
}

\begin{abstract}
Lyme disease (LD) is the most common tick-borne disease in the northern hemisphere, producing a wide range of disabling effects on multiple human targets, including the skin, the nervous system, the joints and the heart. Insufficient clinical diagnostic methods, the necessity for prompt antibiotic treatment along with the pervasive nature of infection impel the development and establishment of new clinical diagnostic tools with increased accuracy, sensitivity and specificity. The goal of this article is 4-fold: (i) to detail LD infection and pathology, (ii) to review prevalent diagnostic methods, emphasizing inherent problems, (iii) to introduce the usage of in vivo induced antigen technology (IVIAT) in clinical diagnostics and (iv) to underscore the relevance of a novel comprehensive LD diagnostic approach to practitioners of Complementary and Alternative Medicine (CAM). Utilization of this analytical method will increase the accuracy of the diagnostic process and abridge the time to treatment, with antibiotics, herbal medicines and nutritional supplements, resulting in improved quality of care and disease prognosis.
\end{abstract}

Keywords: Borrelia burgdorferi - in vivo-induced antigen technology - Lyme disease multi-peptide ELISA

\section{Introduction}

Bacterial infection with specific spirochetes from the genus Borrelia, usually acquired from the bite of an infected Ixodes tick, is the cause of Lyme disease (LD). The species complex B. burgdorferi sensu stricto is predominantly responsible for LD cases in the United States while $B$. burgdorferi sensu lato, $B$. afzelii and $B$. garinii are the responsible pathogenic species in Europe and Asia $(1,2)$.

Presentation and destructive effects of LD vary widely depending on the stage and magnitude of spirochete dissemination. Initial effects may include rashes or flu-like symptoms, while later stages may be characterized by arthritic, neurological, psychiatric and cardiac symptoms.

For reprints and all correspondence: Aristo Vojdani, Immunosciences Lab., Inc., 8693 Wilshire Blvd., Suite 200, Beverly Hills, CA 90211,

USA. Tel: + 1-310-657-1077; Fax: + 1-310-657-1053;

E-mail: drari@msn.com
Due to the varying nature of symptom appearance there exist a number of DNA technologies and serological methods that may be utilized, in conjunction with clinical examination, to support and confirm a diagnosis of LD; however, the techniques maintain certain pitfalls. Divergent symptoms between infected individuals and flawed clinical diagnostics hinder accurate diagnosis and prompt antibiotic treatment, which are essential for a good prognosis and the prevention of chronic infection (3).

The conventional treatment for LD is a course of antibiotic therapy, such as doxycycline, amoxicillin, penicillin, erythromycin and other antibiotics listed in Table 1. Maximal efficacy of oral antibiotic administration is rendered in the early stages of infection, typically days or weeks following pathogen introduction. At the chronic stage of the disease, administration of a combination of these medications orally, intramuscularly and intravenously is required for several months before an attenuation of infection is apparent (4-8). 
Table 1. CAM treatment of Lyme disease with a combination of different antibiotics, herbal remedies, and nutritional supplements, with pertinent references

\begin{tabular}{|c|c|c|c|c|}
\hline $\begin{array}{l}\text { Antibiotics used for treatment of } \\
\text { Lyme disease (Refs } 6-8,10,11)\end{array}$ & Herbal remedies & Ref & Nutritional supplements & Ref \\
\hline Minocycline & Cumada & (24) & Coenzyme-Q10 & (26) \\
\hline Augmentin & Allicin & $(25)$ & Grapeseed Extract & (26) \\
\hline Azithromycin & Dragon's blood & $(25)$ & Magnesium & $(24)$ \\
\hline Erythromycin & Devil's claw & $(24)$ & $\alpha$-Lipoic acid & $(14,15)$ \\
\hline Vaucomycin & Echinacea & $(25-28)$ & Dimethylglycine & $(27)$ \\
\hline Clarithromycin (biaxin) & $\begin{array}{l}\text { Citriodiol } \\
\text { (lemon eucalyptus extract) }\end{array}$ & (9) & Vitamin B-complex & $(4,8)$ \\
\hline Cefuroxime axetil & Astragallus & (29) & Methylcobalamin & $(4,8)$ \\
\hline Plaquenil & Boswellia & (26) & Pycnogenol & $(27)$ \\
\hline Taurox $\mathrm{SB}^{\mathrm{TM}}$ & Parsley extract & (24) & $N$-Acetylcysteine and glutathione & (26) \\
\hline Colloidal silver & Red chili pepper (capsaicin) & $(18)$ & Probiotics & (23) \\
\hline \multirow[t]{2}{*}{ Imipinem } & Quercetin & $(21)$ & Dehydroepiandrosterone & $(12)$ \\
\hline & & & Royal Jelly & (26) \\
\hline
\end{tabular}

The swiftness in diagnosis is further emphasized by the characteristic abilities of Borrelia, via antigenic changes on its surface, to avoid the immune system and subsequently infiltrate areas of the body maintaining low levels of drug distribution, such as the joints and nervous system. Due to this complexity, Complementary and Alternative Medicine (CAM) holds great promise for the abrogation of disease pathology through the combination and utilization of accurate diagnostic methods and effective treatment modalities (9-30).

The CAM treatment for LD, summarized in Table 1, combines intravenous antibiotic therapy, herbal medicine administration and nutritional medicine to enhance the immune system's ability to fight this intracellular microorganism (9-30).

Considering the side effects of antibiotics and the length of this treatment with CAM modalities, an effective procedure for diagnosis of $\mathrm{LD}$ is needed to justify such a course. A novel diagnostic approach to LD, utilizing in vivo induced antigen technology (IVIAT) and enzyme-linked immunosorbent assay (ELISA), may provide the data necessary to justify CAM treatment of LD and associated spirochetes. Therefore, it is imperative to review the merit of this diagnostic approach, which will expedite the accurate diagnosis of LD, in order to emphasize its importance to practitioners of CAM in areas of the world greatly affected by LD (31-34).

\section{Prevalent Diagnostic Techniques: The Benefits and Inherent Drawbacks}

A number of diagnostic tests for LD aim to detect the presence of Borrelia antigens and related immune system components (35-39). While the theory behind the development of these techniques was sound, these tests suffer from false results (40); recent research has served to give an understanding as to the reasons underlying such inaccuracies.

Polymerase chain reaction (PCR) for LD attempts to detect the DNA of the spirochete. In a recent study, urine-based PCR for LD was evaluated and shown to be insufficient for a diagnosis (35).

The Center for Disease Control (CDC) proposes a twotiered approach to LD diagnosis (36). This includes an initial screening test such as ELISA with high sensitivity, which is followed by an immunoblot with high specificity.

\section{ELISA and Initial Screening Test for LD}

The Lyme ELISA test is intended for the quantitative detection of $\operatorname{IgG}$ and $\operatorname{IgM}$ antibodies to B. burgdorferi in human serum. Titers of IgG are generally low during the first weeks of illness. They peak within three to six weeks after onset but are often not detectable in symptomatic patients (37). This assay is performed based on crude 
preparation of B. burgdorferi in culture and its binding to solid phase matrix. IgG and $\operatorname{IgM}$ antibodies in patients serum binds specifically to antigen coated wells resulting in color development. The intensity of color is equivalent to the level of antibodies.

\section{Western Immunoblot Assay for Confirmation of LD}

The western blot assay has been widely used to detect the presence of antibodies in human serum and plasma to various infectious disease agents. In this procedure, component proteins of purified, inactivated bacteria are electrophoretically separated by SDS-polyacrylamide electrophoresis followed by electrotransfer to nitrocellulose sheets (38). Each strip served as the solid-phase antigen for an ELISA test. The western blot assay is more reliable since the cross-reactive antibodies are excluded and peptide specific antibodies are observed. However, if antibodies are not present in the blood, false negative results will be obtained (39).

\section{Drawbacks of Serodiagnosis of LD}

The current problems with serodiagnosis of LD include a lack of standardization and poor evaluation criteria regarding sensitivity and specificity. These troubles are due in part to the broad heterogeneity of the immunodominant antigens from disease causing Borrelia strains and the utilization of a single strain in the whole-cell lysate immunoblot assay (36). It is thought that the usage of several strains of different species would increase assay sensitivity; while the usage of multiple Borrelia species grown in culture does provide a broader set of antigens, it is not sufficient due to antigenic variations and expression employed by Borrelia to avoid immune destruction in the mammalian system (40-43). Therefore, it is crucial to combine clinical symptomology with sensitive techniques such as IVIAT Multi-Peptide ELISA that take into account antigenic variation.

\section{In Vivo Included Antigen Technology: The Key to Enhanced Specificity}

IVIAT is a technique that identifies pathogen antigens that are immunogenic and expressed in vivo during human infection. Regulating gene expression optimizes a pathogen's ability to proliferate within specific environments, inducing or repressing specific genes to enhance growth within the host during infection, thus contributing to overall pathogenicity (41-43).

IVIAT identification of these Borrelial gene products, especially antigens from variable regions, during infection may be utilized to develop enhanced diagnostic methods (43). The chronic nature of LD and the antigenic diversity of the spirochetes suggest the spirochete undergoes dramatic changes in antigenic composition as it cycles between its arthropod and mammalian hosts and that this variation plays an important role in immune detection and destruction. Major proteins or lipoproteins called variable major protein (VMP) or VMP-like sequence (VlsE) are responsible for this antigenic variation strategy evolved to avoid immune detection and destruction $(44,45)$.

Furthermore, different membrane surface protein $\mathrm{E}$ (OSPE) enables the spirochete to evade the immune system and to maintain chronic infection (46-48). In this multi-peptide ELISA assay based on IVIAT (32-34), we selected peptides from different components of Borrelia during specific life cycles, including:

\section{Outer Surface Proteins and Leukocyte Function Associated Antigen}

A prominent late manifestation of B. burgdorferi infection is Lyme arthritis. Development of antibody reactivity to outer surface protein A (OspA) occurs towards the beginning of prolonged arthritic episodes (49). The progression to an autoimmune state begins with a cross-reactive response between OspA and a self-antigen, e.g. leukocyte function associated antigen (LFA). Identification of a bacterial antigen that displays crossreactivity with an autoantigen may provide a model for development of autoimmune disease induced by B. Burgdorferi and provide an important antigen to incorporate into diagnostic methods (50). Outer surface protein $\mathrm{C}(\mathrm{OspC})$ is thought to be an important virulence factor involved in the transmission and establishment of early infection $(51,52)$. Borrelia burgdorferi reduces the expression of $\mathrm{OspC}$ in response to the development of antibodies, indicating the importance of repressing OspC expression to avoid clearance and to maintain infection (53-55). Since humans produce highly specific antibodies against $\mathrm{OspC}$, measurement of $\mathrm{IgG}$ and $\mathrm{IgM}$ antibodies against this highly conserved epitope indicate recent infection with $B$. burgdorferi. The Outer surface protein $\mathrm{E}(\mathrm{OspE})$ is expressed in both ticks and mammals, and elicits a strong antibody response. Specificity of antibody response with different OspE variants suggests that the hypervariable regions of $\mathrm{OspE}$ are targeted by the antibody response during infection. Consequently, it is important to assess the specificity of the antibody response to OspE epitopes during infection and incorporate this information into a testing method to target antibodies to OspE (56).

\section{Immunodominant Antigens}

Two peptides, termed $\mathrm{C} 2$ and $\mathrm{C} 6$, are conserved across B. burgdorferi sensu lato, B. burgdorferi sensu stricto and B. garinii (44-47). Antigenicity of these peptides is supported by the observation that sera from humans, 
monkeys and mice react with $\mathrm{C} 2$ and $\mathrm{C} 6$ peptide early and persistently through the course of infection, indicating that these peptides contain one or more epitopes that are broadly antigenic (57).

In a study of human serum samples collected in the northeast and mid-west of the US, from patients with acute or chronic LD, 35 of the 41 samples reacted with and presented significant levels of antibodies against the C6 peptide. The five serum samples that had no detectable levels of antibodies against the C6 peptide were obtained from patients who were in the early stage of infection (58).

\section{Variable Major Protein}

The spirochetes that cause LD express the surface lipoprotein VMP or VlsE (45). Infection-induced sequence changes that alter antigenic properties of VlsE contribute to immune evasion. In an experimental model a strong VlsE IgG antibody response was apparent by the fourth week of infection, indicating that VlsE is expressed during early stage of infection. Serum samples from LD patients also possessed VlsE antibodies that were immunoreactive against all species of Borellia (45). This indicates that there are conserved epitopes among VlsE variants that are antigenic during infections. Based on these experiments, researchers employed recombinant VlsE in an ELISA test and demonstrated diagnostic sensitivities of $63 \%$ for culture-confirmed LD erythema migrans (EM) cases and $92 \%$ for late stage LD infections.

\section{Peptides from Complement Regulator Acquiring Surface Protein-1 (CRASP-1)}

It is well known that the three different genospecies of B. Burgdorferi exhibit distinct disease manifestations and tissue tropisms during mammalian infection considering the ability of pathogenic Borrelia sp. to survive intracellular in the mammalian host, these spirochetes must have developed efficient strategies for circumventing the innate immune response (59-61). Along these lines, it has been suggested that CRASPs are key mediators that allow B. burgdorferi to evade the innate immune response and complement-mediated destruction during the acute stage of infection. Thus CRASP-1 expression is necessary for B. burgdorferi to resist killing by human serum $(59,61)$.

\section{Peptides from Decorin Binding Protein for Species-Specific Serodiagnosis of Lyme Arthritis and Neuroborreliosis}

Among individual Borrelial proteins from different species, sequence heterogeneity varies up to $40 \%$ $(62,64)$. Decorin binding protein A, a Borrelial outer surface protein, is one of the key proteins. This antigen elicits a strong antibody response during experimental murine borreliosis and has been suggested as a potential vaccine protein (65). Decorin binding protein-peptide from $B$ sensu stricto, $B$. garinii and $B$. afzelii were produced and tested as antigens by ELISA.

One hundred percent of patients with neuroborreliosis (NB) and $93 \%$ of patients with Lyme arthritis (LA) reacted positively. Sera from the majority of patients reacted with one rDbpA only and had no or low crossreactivity to other variant proteins. In patients with culture-positive EM, the sensitivity of rDbpA immunoglobulin $\mathrm{G}(\mathrm{IgG})$ or IgM ELISA was low. The DbpA seems to be a sensitive and specific antigen for the serodiagnosis of LA or NB, but not of EM (65).

\section{Arthritis-Related Protein or Glutathione-S-Transferase}

In addition, a $37-\mathrm{kDa}$ arthritis-related protein of B. burgdorferi outer-surface protein, termed arthritisrelated protein (Arp), has been shown to prevent or reduce the severity of arthritis. Antibody responses to this single protein resembling glutathione-S-Transference were tested on 124 antibiotic-treated patients with early or late manifestations of LD (66). Among the 124 antibiotictreated patients, 53\% with culture-proven EM had IgG responses to recombinant glutathione S-transferase (GST)-Arp, as did $59 \%$ of the patients with facial palsy and $68 \%$ of those with LA. Therefore, measurement of antibody against recombinant GST may be additional tool for detection of $B$. burgdorferi involvement in patients with accompanying arthritis during initial episodes of joint pain or during the maximal period of arthritis (66).

\section{Antigens from Cross-Reactive Spirochetes and Other Bacteria}

Three genera, Treponema, Borrelia and Leptospira contain pathogenic spirochetes that cause disease in humans. All spirochetal disease share remarkable similarities in clinical manifestations including spirochetemia, in the early stages of the disease, dissemination of spirochetes to body organs, skin lesions, one or more stages of the disease are frequently interrupted by a period of latency, and neurological and cardiac involvement (67). In addition to similarities of their clinical conditions, cross-reactivity in all antibody assays including ELISA and western blot has been observed with treponema and leptospira (67). This cross-reactivity in an antibody assay could be related to Borrelia hermsii, which is a cause of relapsing fever (68), Babesia microti, which causes Babesiosis (69), Ehrlichia or the agent of human granulocytic ehrlichiosis (Anaplasma phagocytophilia) $(69,70)$ and Bartonella henselae, which can cause CatScratch disease in a human (71, 72). In addition, serological cross-reactivity between $B$. burgdorferi and bacteria such as a Yersinia enterocolitica outer membrane protein was shown in a recent study (73). 
Yersinia enterocolitica and Yersinia pseudotuberculosis have been identified as causative organisms of reactive arthritis in humans. Cross-reactivity between Yersinia and $B$. burgdorferi indicates that molecular mimicry between bacteria that does not belong to genus Borrelia with $B$. burgdorferi is possible (74). This includes other arthrogenic bacteria such Salmonella and Shigella, which antibodies against them are detected in $67 \%$ of patients with LD (75). Due to the extensive evidence of crossreactivity between Treponema, Leptospira, Babesia, Ehrlichia, Bartonella and other bacteria that do not belong to the genus Borrelia, particularly Yersinia with $B$. Burgdorferi, the diagnosis of LD should be based on clinical findings and complete serological analysis of $B$. burgdorferi antibodies and the exclusion of its crossreactive microorganisms $(74,75)$. Furthermore, antibodies against these spirochetes may result in autoimmune and neurological disorders, which are summarized below:

Autoimmunity Induced by Molecular Mimicry of Peptides from B. burgdorferi and Human Tissue Antigens

Antigenic mimicry of infectious agents and auto-antigens is a proposed patho-mechanism for autoimmune diseases. For example, multiple auto-antigen mimotopes of infection agents (Shigella, Rotavirus and Klebsiella), were shown to induce autoimmune arthritis and uveitis in rats $(73,75)$, multiple microbial peptides (76) and Chlamydia pneumonia, specific peptides in multiple sclerosis $(77,78)$, Campylobacter jejuni in Guillain-Barre Syndrome (79) and $Y$. enterocolitica and autoimmune thyroid disease (80). In this regard spirochete $B$. burgdorferi could be another trigger, which is an amino acid sequence homology with self antigen that may trigger multiorgan system disorder in genetically predisposed individuals (80). For example, using a basic local alignment search (BLAST), four matched with $Y$. enterocolitica, and five matched with B. burgdorferi and thyroid stimulating hormone receptor (TSH-R), up to $50 \%$ identity and similarity were detected. Through this, it was concluded that Borrelia and Yersinia as environmental triggers can induce autoimmune thyroid disease in a genetically predisposed person through molecular mimicry mechanisms (80). Another target antigen for autoimmune reaction downstream of the original bacterial infection is cytokeratin-10 (81). These auto-antibodies in synovial lesions of chronic antibiotic treatment-resistant LA are due to cross-reactivity between cytokratin 10 and a prominent outer surface protein A of B. burgdorferi (81). This cross-reactivity suggests a degree of antigenic mimicry that might contribute toward setting the stage for autoimmunity, sustaining the response originally elicited by B. burgdorferi long after elimination of the spirochete.

This autoimmune reaction in LA may occur through different mechanism of action and by utilization of proteases from its mammalian hosts to degrade extra cellular matrix proteins. Binding of B. burgdorferi to the host plasminogen and its activator Urokinase, is able to induce the production of the matrix metalloproteinases (MMPs) and degradation of extra cellular matrix proteins that allows $B$. burgdorferi to disseminate in the tissue (82).

This up regulation of MMPs not only plays a role in dissemination of the organism through extra cellular matrix tissue, but it can also result in destructive pathology (83). Among the MMPs that have been suggested to participate in cartilage degradation in patients with rheumatoid arthritis are collagenases (MMP-1, -8 and -13), stromelysins (MMP-3, -10 and -11), and gelatinases (MMP-2 and -9) (84).

Borrelia burgdorferi is dependent upon the mammalian or tick host for the provision of amino acids and other required components. An ABC oligopeptide transporter system, (OPP) has been well characterized as an aminopeptidase. This and other proteases fulfill important roles in both the basic physiology and pathogenesis of many microbial pathogens including the ability to provide required amino acids. These proteases, by providing required amino acids, enhance the growth of spirochetes and their motility through mammalian host tissues (82-84).

\section{Neurological Manifestations of $L D$}

Neurologic involvement in LD occurs in $10-40 \%$ of patients within several weeks to months of the tick bite. Both the peripheral and the central nervous system (CNS) can be involved, although disease in the former occurs more frequently. Early neuroborreliosis manifests as lymphocytic meningitis (sometimes meningoencephalitis), cranial neuropathies and peripheral radiculoneurophathies (85). Patients with meningitis have headaches and meningeal signs. Examination of the CSF shows a lymphocytic pleocytosis with normal glucose. There is often evidence of intrathecal antibody reactive with $B$. burgdorferi antigens, and oligoclonal bands may be present. Direct invasion of $B$. burgdorferi into the subarachnoid space with a secondary immune response is believed to be the cause of meningitis. As with other manifestations of LD, meningitis can revolve spontaneously despite persistent infection (85-87).

Bell's palsy, due to the involvement of cranial nerve VII, is the most common cranial neuropathy, may be bilateral, and is often associated with other peripheral nervous system manifestations. The most common peripheral nervous system manifestation is a mild, patchy, distal sensorimotor (axonal) neuropathy (86). Neurophysiology testing of individuals with radicular symptoms is abnormal, and in some cases, lymphocytic pleocytosis in the CSF is demonstrable 
and associated with inrathecal anti- $B$. burgdorferi antibody production (86).

CNS involvement is relatively uncommon, usually late, and occurs in either of two ways: an acute, disseminated encephalomyelitis and a more indolent, late, slowly progressive parenchymal neurologic disorder resembling multiple sclerosis. Patients with the acute form present with depressed mental status, cognitive deficits and multifocal abnormalities on neurologic examination. Magnetic resonance imaging (MRI) scans of the brain reveal predominantly white matter lesions, and the CSF examination can exhibit both lymphocytic pleocytosis and intrathecal anti-B. burgdorferi antibody production. These patients respond well to antibiotic therapy with little, if any, residual deficit $(85,86)$. In contrast, patients with slowly progressive inflammatory CNS neuroborreliosis have often been misdiagnosed with multiple sclerosis and have received immunosuppressive treatment to stabilize their neurologic deficits. These patients have white matter lesions on brain MRI scans, which had led to the speculation that this form of neuroborreliosis is a demyelinating disorder (86).

The presence of decorin binding protein $\mathrm{B}$ of B. burgdorferi and antibody against it has been detected in cerebrospinal fluid of patients with neurologic LD. This indicates that B. burgdorferi may enter the CNS after infection. To infect the brain, the circulating spirochetes must first cross the blood-brain barrier (BBB). This barrier is composed of tightly apposed brain microvascular endothelial cells held together by that tight junction (87). Several bacteria express their own proteases that digest the extracellular matrix in order to invade tissues, but other bacteria, like B. burgdorferi, appear to utilize the fibrinolytic system of the host to disseminate $(87,88)$. Borrelia burgdorferi and Borrelia crocidurae spirochetes use the fibrinolytic system it disseminates into host tissues, including the brain. At the same time $B$. burgdorferi induces the expression and secretion of the urokinase-type plasminogen activator (uPA) and expression of the uPA receptor (UPAR) by a variety of cell types. As the fibrinolytic system can directly digest components of the extracellular matrix, it can also activate other proteases, including MMPs. Not only do these enzymes naturally occur in the blood circulation, but they are also expressed as a result of the interaction between the host cells and B. burgdorferi (89). To prove the transversal of $B$. burgdorferi across the human BBB and systematic endothelial cell barriers in vitro model systems constructed of human brain microvascular endothelial cells (BMEC), a human umbilical vein endothelial cell (HUVEC) line where used (90). Results showed that B. burgdorferi differentially crosses human BMEC and HUVEC and that the human BMEC from a barrier to traversal. Importantly, traversal of $B$. burgdorferi across human BMEC induces the expression of plasminogen activators, activator receptors and MMPs.
This fibrinolytic system linked by an activation cascade may lead to focal and transient degradation of tight junction proteins that allows $B$. burgdorferi to invade CNS (90).

In addition to the activation of the fibrinolytic system, entry of spirochetes into the CNS may result in a severe inflammatory reaction, producing proinflammatory cytokines such as interferon- $\gamma$ and TNF- $\alpha$. The cytokine reaction with neuronal cells may result in a neural cell antigen release and entry in circulation and induction of both cellular and humoral immune reaction against myelin ganglioside, sulfatides and many other selfantigens. Therefore, the complementary approach to the diagnosis and treatment of LD could not be based only on ELISA, western blot or Multi-Peptide ELISA assay for detection of antibodies against Borrelia-specific antigens (32-34), but against other cross-reactive microorganisms and different tissue antigens mentioned in this chapter. Measurements of $\operatorname{IgG}, \operatorname{IgM}$ and $\operatorname{IgA}$ antibodies against these important antigens that are related to $\mathrm{LD}$ are summarized in Table 2.

\section{Mechanisms by which Tick Salivary Protein-15 Facilitates Bacterial Invasion}

The causative spirochete of LD not only employs means to change antigenic structures, but also borrows a practical coat from the saliva of its vector, the Ixodes tick $(91,92)$. The coating is present on the many active molecules introduced into the mammalian host during attachment and feeding. The LD bacterium replicates and resides in the mid-gut of an infected tick and moves transiently through the salivary glands during tick feeding. This transition into the salivary glands is accompanied by a major phenotypic switch at the bacterial surface, from expression of OspA to OspC $(91,92)$.

Binding of OspC to salivary protein-15 (Salp15) in tick saliva facilitates bacterial invasion of, and binding to, salivary glands. This suggests that one function of OspC is to serve as a ligand for a salivary gland receptor. The function of Salp15 is to inhibit IgG antibody response to foreign antigens by halting CD4 $+\mathrm{T}$-Cell activation, and inducing immune suppression, by binding to a receptor on the CD4 + T-Cell $(91,92)$. A direct connection occurs between $\mathrm{CD} 4+$ and $\mathrm{C}$-terminal amino acid residues of Salp15, allowing for Salp15 to act at the very beginning of the signaling cascade initiated by T-Cell receptor binding (92). This Salp15-mediated immunosuppressive mechanism, along with the activation of the fibrinolytic system and proinflammatory cytokine production, allows for facilitated invasion of the host's immune and CNSs, as is shown in Fig. 1. This figure shows that after a tick bite, in addition to $B$. burgdorferi, tick salivary proteins enter the host and exert an immunosuppressive effect (A). 
Table 2. CAM approach for comprehensive measurement of antibodies against Borrelia-specific antigens that are expressed in vitro and in vivo, their cross-reactive microorganisms and target tissue antigens

\begin{tabular}{|c|c|c|}
\hline Borrelia specific antigens & Cross-reactive microorganisms & Target tissue antigens or enzymes \\
\hline B. Burgdorferi lysate & Treponema palidum & Thyroid stimulating hormone receptor \\
\hline Outer surface protein-A & B. microti & Cytokeratin-10 \\
\hline Outer surface protein- $\mathrm{C}$ & Ehrlichia (Anaplasma phagocytophilia) & Plasmin \\
\hline Outer surface protein-E & Bartonella henselae & Plasminogen \\
\hline Leukocyte function associated antigen & $Y$. enterocolitica & Collagenase MMPS 1,2,3 \\
\hline VMP immunodominant (C2 peptide) & B. hermsii & Gelatinase MMPS-9 \\
\hline VMP immunodominant (C6 peptide) & Salmonella & Urokinase \\
\hline Variable major protein like sequence & Shigella & Myosin \\
\hline Complement regulator-acquiring surface Protein-1 & Mycoplasma & Collagen \\
\hline Decorin binding protein of $B$. burgdorferi sensu stricto & Brucella & $\begin{array}{l}\text { Arthritis related protein } \\
\quad \text { (Glutathione S-transferase) }\end{array}$ \\
\hline Decorin binding protein of $B$. burgdorferi garinii & Mycobacteria & Myelin basic protein \\
\hline \multirow[t]{6}{*}{ Decorin binding protein of $B$. burgdorferi afzelii } & Leptospira & Myelin oligodendrocyte glycoprotein \\
\hline & Chlamydia Pneumonia & Ganglioside \\
\hline & Bacterial heat shock protein (HSP-60) & $\alpha-\beta-$ Crystallin \\
\hline & Rota virus & Sulfatide \\
\hline & Klebsiella & Human heat shock protein-60 (H-HSP-60) \\
\hline & Streptococcal M protein & \\
\hline
\end{tabular}

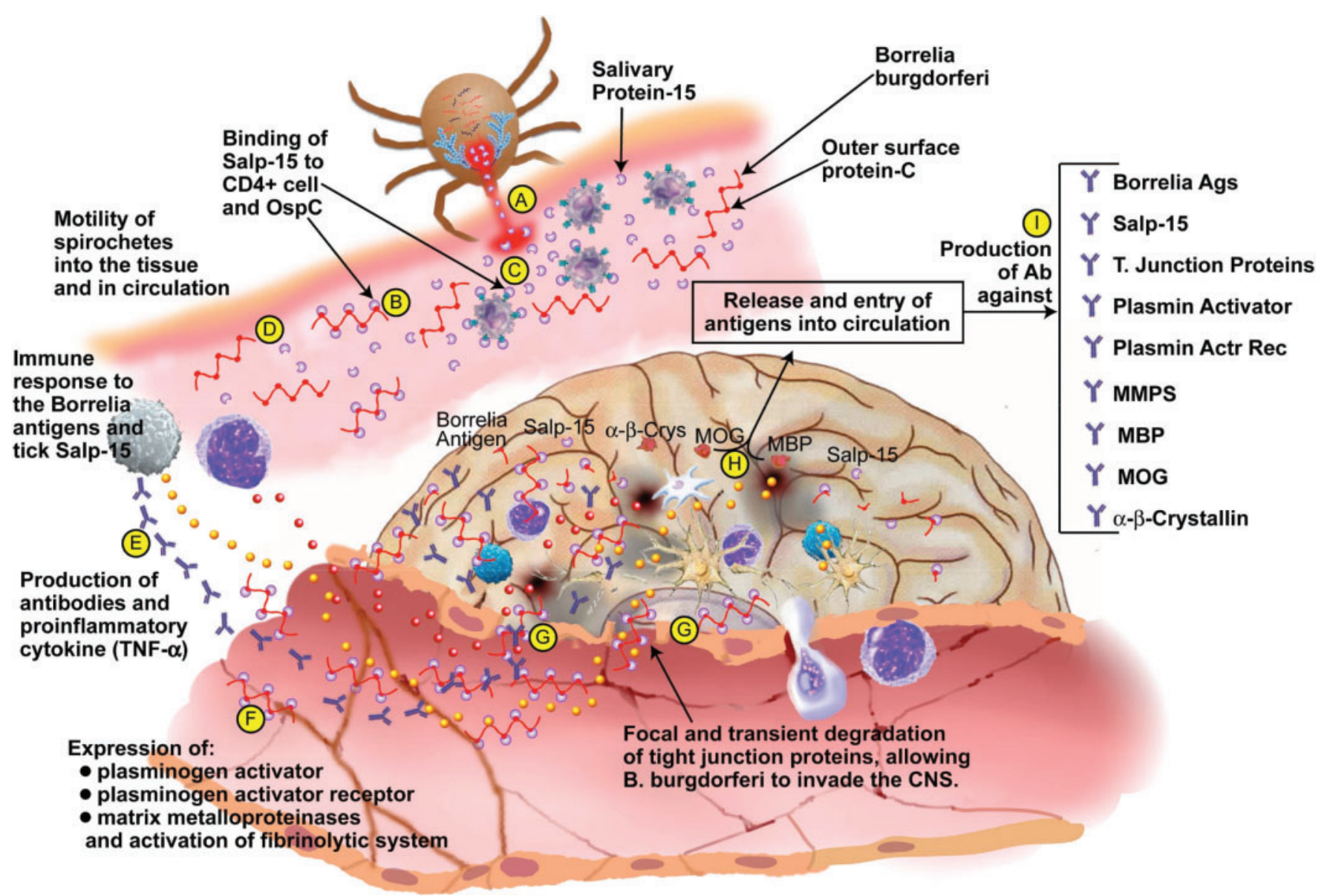

Figure 1. Entry of Borrelia in circulation and different tissue, induction of immuno-suppression with tick salivary protien, activation of the inflammatory and fibrinolytic systmes, and breaking the blood brain abrrier, which allows invasion of the CNS, resulting in neuroborreliosis. 
This is done by tick Salp15 binding to OspC of B. burgdorferi and protecting it from immune attack (B). Salp15 could also bind to CD4 on helper cells, inhibiting TCR ligation-induced-T-cell signaling and immunosuppression (C). This way the spirochete can move freely in the circulation and possibly in different tissues (D). Eventually, immune response to Borrelia and Salp15 occurs, resulting in antibody as well as proinflammatory cytokine production (E). Simultaneously, a few spirochetes may make contact with the endothelial cells of the BBB, stimulating expression of plasminogen activators, plasminogen activator receptors and MMP, all of which contribute to activation of the fibrinolytic system (F). This in turn results in focal and transient degradation of tight junction proteins, allowing B. burgdorferi to invade the CNS $(\mathrm{G})$. This invasion of the CNS may result in the destruction of neuronal cells, the release of neural cell antigens and $(\mathrm{H})$. the production of antibodies against MBP, MOG, $\alpha$-B-crystallin and other neural cell antigens (I). Another possibility for the production of these antibodies against neural cell antigens is through molecular mimicry between outer surface protein A (OspA) and neural tissue (93). DNA sequences of $\mathrm{Bb}$ OspA compared with a data bar of DNA sequences of human neural tissue yielded three sequences that were identical. The three corresponding $\mathrm{Bb}$ peptides were synthesized, and antibodies were induced against them. The antibodies cross-reacted with human neural tissues, including neurons in the human brain, spinal cord and dorsal root ganglia.

These findings imply that antibodies developed by LD patients against OspA will also bind to their own neural tissue, representing a form of autoimmune disease in which a person's immune system attacks his own tissues (93).

\section{CAM Diagnosis and Treatment for LD: Examples of Patients' Results}

LD is a complex and devastating disorder requiring efficient means of diagnosis in order to begin treatment at the onset of infection. We have outlined the method of transmission and the mechanisms of infection and maintenance, both of which provide critical information for developing new diagnostic techniques. During the various life cycles of Borrelia in the body, the expression of different antigens is tightly regulated such that the spirochete may disseminate and survive for long periods of time. We have shown that the variety of antigens, identified through IVIAT (43), is integral to accurately identify infection and indicate the stage of infection. Information gauged from clinical diagnostic methods assessing these two components, most easily implemented into an ELISA method, provides an infection profile from which an appropriate medical treatment may be determined. In addition to IVIAT and its use in multipeptide ELISA, work is being done to develop a method to detect immune response to Ixodes proteins (32-34, 93, 94). Using this novel technology for the diagnosis of LD, examples of four patients with signs and symptoms of LD are depicted in Fig. 2. Each specimen was tested for $\operatorname{IgG}$ and $\operatorname{IgM}$ antibodies simultaneously against $B$. burgdorferi lysate and peptides from outer surface protein-A (OspA) and OspC, OspE, LFA, immunodominant peptides $(\mathrm{C} 2+\mathrm{C} 6)$, VMP, B. b. sensu stricto, B. garinii, B. afzelii, Babesia, Ehrlichia, Bartonella, Treponema palidum, as well as myelin basic protein (MBP), myelin oligodendrocyte glycoprotein (MOG) and collagen as tissue antigens.

Note that in Patient 1, despite presentation of clinical symptomatology of $\mathrm{LD}$, antibodies were not detected against $B$. burgdorferi three tested subspecies, antigens and peptides, Babesia, Ehrlichia, Bartonella, Treponema or tested target tissue antigens. Since symptoms of hundreds of other diseases can overlap with those of LD, the classification of disease should not be based solely on clinical findings but in conjunction with the most sensitive laboratory examinations available. For instance, Patient 2 was classified with Lyme-induced arthritis, but in this case the diagnosis is confirmed by the pattern of detected antibodies, particularly against $B$. burgdorferi lysate and leukocyte function associated antigen, as well as very high levels of antibodies against collagen. In Patient 3, who was classified with neuroborreliosis, the diagnosis was also confirmed by the pattern of detected antibodies against Borrelia antigens and neuroantigens (MBP and MOG).

Finally, Patient 4, who was classified as having multisystem organ disorder, reacted strongly with all16 antigens tested in the assay. While patients of this type with multi-reactive autoantibodies are called universal reactors, it is plausible that Ig-secreting plasma cells and memory $\mathrm{B}$ cells activated by antigens have undergone somatic hypermutation and/or class switch recombination, thereby producing these pathogenic autoantibodies (95). Indeed, defects in B cell check points have been shown to be associated with the development of multireactive autoantibodies in patients with systemic lupus erythematosus or rheumatoid arthritis (96). These four sample patients' test results with four different patterns of reactivity detected only by our novel comprehensive approach to laboratory examinations justifies CAM intervention, as summarized in Table 1 with pertinent references (6-29).

\section{Conclusion}

Researchers and practitioners of CAM understand the necessity for an all-inclusive diagnostic approach and treatment (as shown in Tables 1 and 2) and can bring 


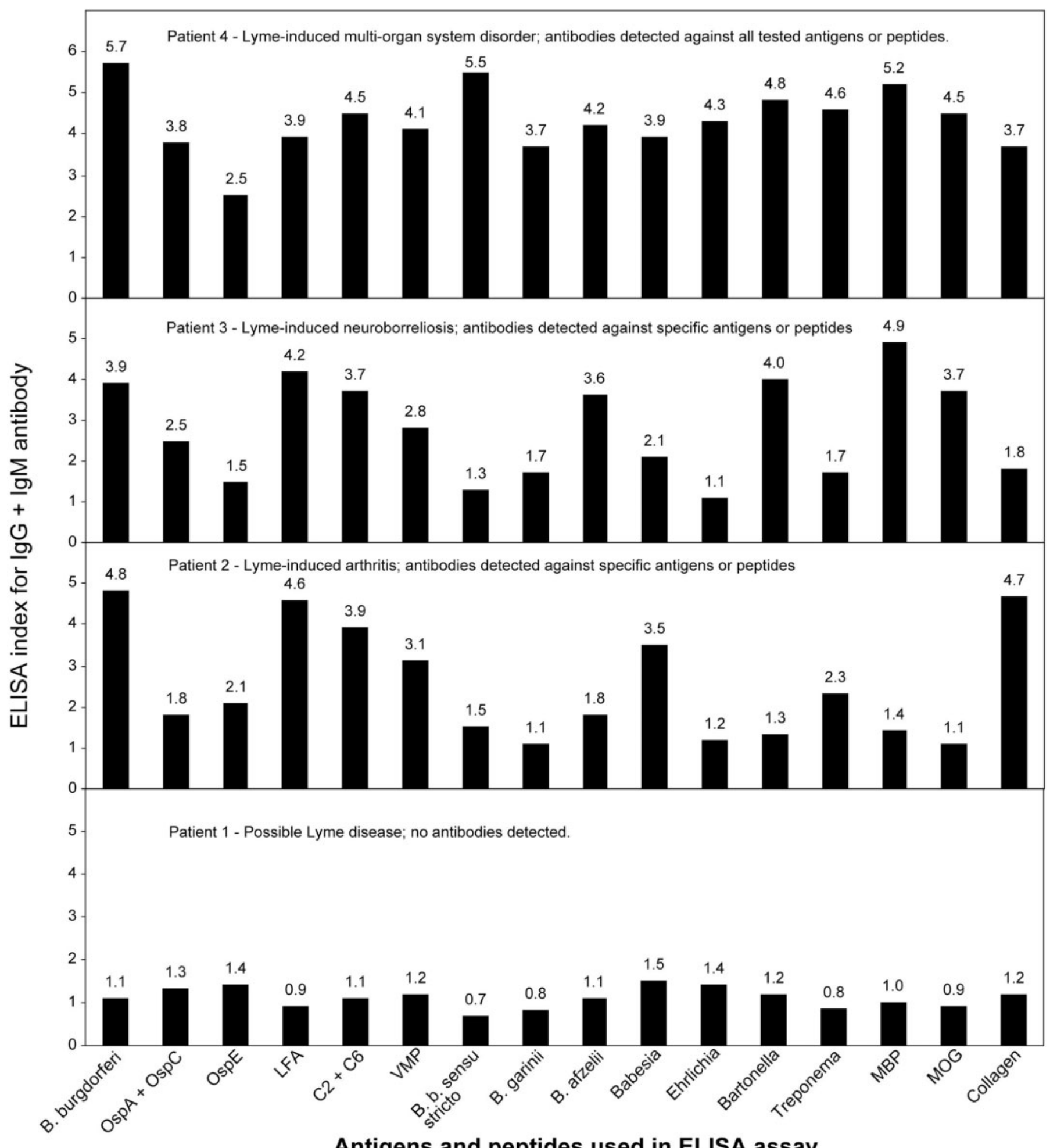

Antigens and peptides used in ELISA assay

Figure 2. IgG + IgM measured against 16 different peptides and antigens from Borrelia, cross-reactive microorganisms (Babesia, Ehrlichia, Bartonella, T. palidum) and target tissue antigens such as myelin basic protein (MBP), myelin oligodendrocyte glycoprotein (MOG) and collagen. Index was calculated based on ELISA optical densities of each specimen obtained at $405 \mathrm{~nm}$ divided by the OD of normal human serum tested against the same antigen or peptide simultaneously. Note that each patient has a different pattern of antibody reactivity against the sixteen different tested antigens or peptides. 


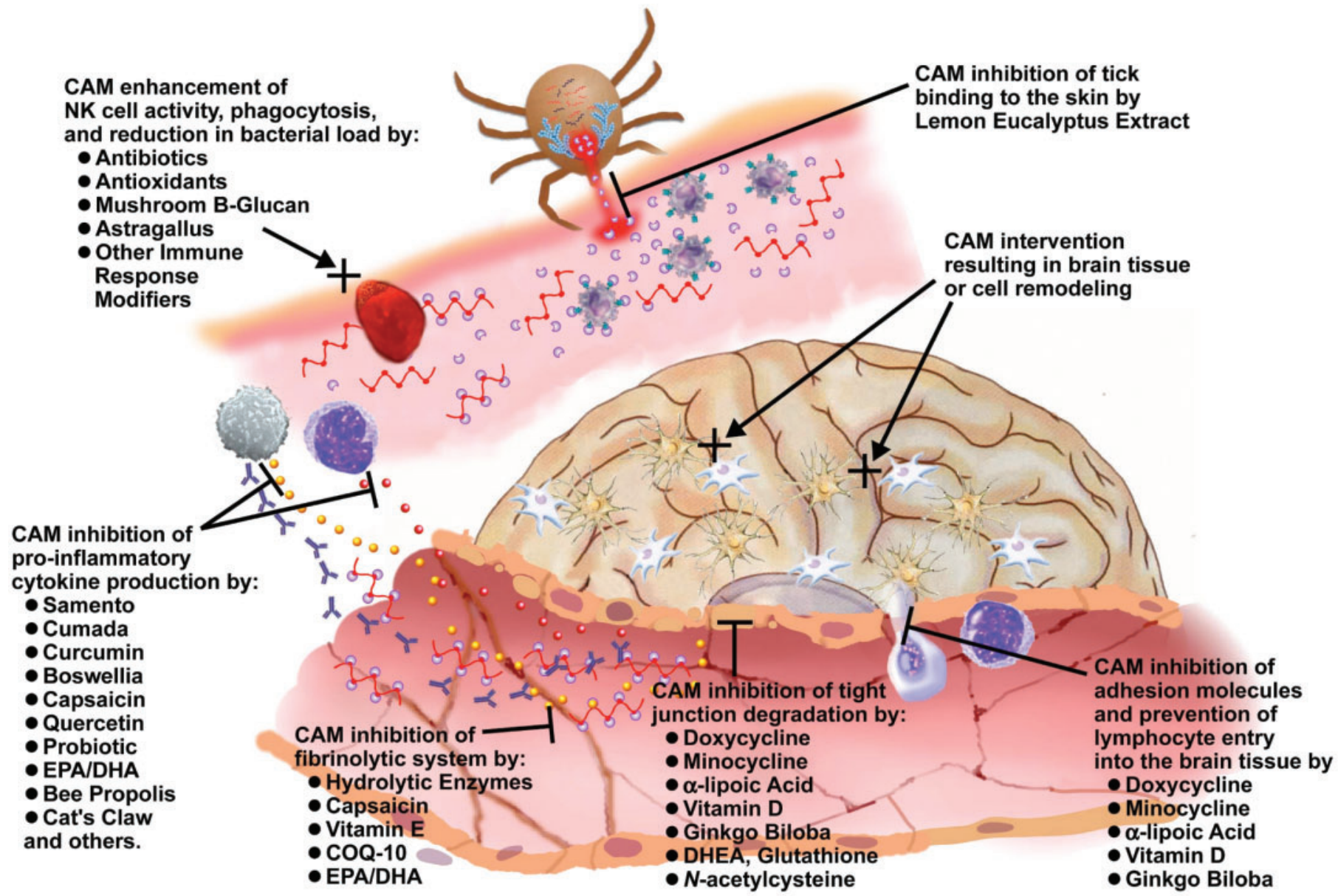

Figure 3. Using CAM treatment could prevent different processes ranging from the attachment of the tick to the inflammatory process, CNS invasion, and the induction of neuroborreliosis. CAM can act through the enhancement of natural killer cell activity, macrophage function, inhibition of pro-inflammatory cytokine production, inactivation of the fibrinolytic system, and repair of blood brain barriers.

new perspectives and ideas to this developmental endeavor. Antibodies against Borrelia-specific antigens and their cross-reactive microorganisms and target tissue antigens shown in Table 1 can be detected in blood long before people show symptoms of various autoimmune disorders. We conclude, therefore, that tests that can detect these predictive autoantibodies could warn of the need to take preventive action by CAM practitioners.

CAM treatment of chronic LD, in addition to a combination of antibiotics, includes a variety of herbal and nutritional supplements. These herbal and nutritional supplements provide different intervention strategies for CAM practitioners (Table 2). These actions of CAM (summarized in Fig. 3) show that different herbal and nutritional remedies are available to prevent the binding of tick to skin, to reduce bacterial load by enhancement of NK cell activity and phagocytosis, to down-regulate proinflammatory cytokines and inhibit the fibrinolytic system, and repair the BBB. All of these improvements can result in elimination of Borrelia from the tissue and decline in cross-reactive antibodies in the blood.

This approach, which was recently covered in an article published in Scientific American, concluded that one day y-shaped molecules called autoantibodies in a patient's blood may tell doctors whether a patient is 'brewing' certain diseases and indicate when the onset of symptoms will occur in the individual (97). Applying this approach, CAM can make a difference in patients with active or chronic LD who have been given little hope by conventional medical doctors. This tailored treatment for LD by CAM practitioners should be designed specifically for each patient, based on clinical findings and laboratory examination for neuroautoimmunity. In this regard the emphasis should be on immunoregulation and enhancement of cell-mediated immunity (microphage function, NK cell function) and not enhancement of humoral immunity and antibody production, since induction of antibody production may actually worsen 
the autoimmune reaction or autoimmune disease exhibited in many patients with LD.

\section{Acknowledgements}

We gratefully acknowledge the valuable insight and suggestions that were contributed by Professor Edwin L. Cooper towards reviewing this manuscript, as well as the wonderful illustrations that were created by Mr Joel Bautista.

\section{Conflict of Interest}

Aristo Vodjani is co-owner and CEO of Immunosciences Lab, Inc. He declares no conflict of interest.

\section{References}

1. Steere AC, Grodzicki RL, Kornblatt AN, Craft JE, Barbour AG, Burgdorfer W, et al. The spirochetal etiology of Lyme disease. N. Engl. J. Med. 1983;308:733-40.

2. Steere AC. Lyme disease. N. Engl. J. Med. 1989;321:586-96.

3. Kantor FS. Disarming Lyme disease. Scientific American 1994;271:34-9.

4. Bock SJ. The integrative treatment of Lyme disease. Int. J. Integ. Med. 1999;1:19-23.

5. Howenstine J. New ideas about the cause, spread and therapy of Lyme disease. Townsend Letter for Doctors 2004;252:64-7.

6. Dattwyler RJ, Volkman DJ, Coanty SM, Platkin SP, Luft BJ. Amoxicillin plus probenecid versus doxycycline for treatment of erythema migrans borreliosis. Lancet 1990;336:1404-6.

7. Luger SW, Paparone P, Wormser GP, Nadelman RB, Grunwaldt E, Gomez G, et al. Comparison of cefuroxime axetil and doxycycline in treatment of patients with early Lyme disease associated with erythema migrans. Antimi crob. Agents Chemother. 1995;39:661-7.

8. Nicolson GL. Diagnosis and therapy of chronic systemic co-infections in Lyme disease and other tick-borne infectious diseases. Townsend Letter 2007;93-8.

9. Gardulf A, Wolfhart I, Gustafson R. A prospective crossover field trial shows protection of lemon eucalyptus extract against tick bites. J. Med. Entemol. 2004;41:1064-7.

10. Tikka TM, Koistinaho JE. Minocycline provides neuroprotection against $N$-methyl-D-aspartate neurotoxicity by inhibiting microglia. J. Immunol. 2001;166:7527-33.

11. Hoyt JC, Ballering J, Numanami H, Hayden JM, Robbins RA. Doxycycline moderates nitric oxide production in murine lung epithelial cells. J. Immunol. 2006;176:562-72.

12. Du C, Khalil MW, Sriram S. Administration of dehydroepiandrosterone suppresses experimental allergic encephalomyelitis in SJL/J mice. J. Immunol. 2001;167:7094-101.

13. Spach KM, Nashold FE, Dittel BN, Hayes CE. IL-10 signaling is essential for 1, 25-dihydrooxyvitamin D3-mediated inhibition of experimental autoimmune encephalomyelitis. J. Immunol. 2006;177:6030-7.

14. Ha H, Lee JH, Kim HM, Kwak HB, Lee S, Kim HH, et al. $\alpha$-Lipoic acid inhibits inflammatory bone resorption by suppressing prostaglandia $\mathrm{E}_{2}$ synthesis. J. Immunol. 2006;176:111-7.

15. Schreibert G, Musters RJP, Reijerkerk A, de Groot LR, van der Pol Hendricx EML, Dopp ED, et al. Lipoic acid affects cellular migration into the central nervous system and stabilizes blood-brain barrier integrity. J. Immunol. 2006;177:2630-7.

16. Targoni OS, Tary-Lehmann M, Lehman PV. Prevention of murine EAE by oral hydrolytic enzymes. J. Autoimm. 1999;12:191-8.

17. Mynott TL, Ladhams A, Scarmato P, Engwerda CR. Bromelain from pineapple stems proteolytically blocks activation of extracellular regulated kinase-2 in $\mathrm{T}$ cells. J. Immunol. 1999;163:2568-75.
18. Beltran J, Ghosh AK, Basu S. Immunotherapy of tumors with neuroimmune ligand capsaicin. J. Immunol. 2007;177:3260-4.

19. Kim HY, Park EJ, Joe EH, Jou I. Curcumin suppresses Janus kinase-stat inflammatory signaling through activation of $\mathrm{Src}$ homology 2 domain-containing tyrosine phospatase 2 in brain microglia. J. Immunol. 2003;171:6072-9.

20. Gururajan M, Dasu T, Shahidain S, Jenning CD, Robertson DA, Rangnekar VM, et al. Spleen tyrosine kinase, a novel target of curcumin is required for B lymphoma growth. J. Immunol. 2007;178:111-21.

21. Nair MP, Mahajan S, Reynolds JL, Aalinkeel R, Nair H, Schwartz SA, et al. The flavonoid Quercetin inhibits proinflammatory cytokine TNF- $\alpha$ gene expression in normal peripheral blood mononuclear cells via modulation of NF-KB system. Clin. Vaccine Immunol. 2006;13:319-28.

22. Lin H, Cheung SWY, Nesin M, Cassileth BR, Cunningham Rundles S. Enhancement of umbilical cord blood cell hematopoiesis by mitake beta-glucan is mediated by granulocyte colony-stimulating factor production. Clin. Vaccine Immunol. 2007;14:21-7.

23. Di Giacinto C, Marinaro M, Sanchez M, Strober W, Boirivant M. Probiotics ameliorate recurrent TH1-mediated murine colitis by inducing IL-10 and IL-10-dependent TGF- $\beta$-bearing regulatory cells. J. Immunol. 2005;174:3237-46.

24. Arthur S. The effectiveness of Samento, Cumada, Burbur and Drl Lee Cowden's protocol in the treatment of chronic lyme disease. Townsend Letter 2007:101-6.

25. Duke JA. Herbs with anti-Lyme potential. Townsend Letter 2007;114-7.

26. Vojdani A, Erde J. Regulatory T cells, a potent immunoregulatory target for CAM researchers: The ultimate antagonist (I). eCAM 2006;3:209-15.

27. Vojdani A, Erde J. Regulatory T cells, a potent immunoregulatory target for CAM researchers: Modulating allergic and infectious disease pathology (II). eCAM 2006;3:1-6.

28. Vojdani A, Erde J. Regulatory T cells, a potent immunoregulatory target for CAM researchers: Modulating tumor immunity, autoimmunity and alloreactive immunity (III). eCAM 2006;3:309-16.

29. Rosenbaum M, Vojdani A, Susser M, Watson CM. Improved immune activation markers in chronic fatigue and immune dysfunction syndrome (CFIDS) patients treated with thymic protein A. J. Nutrit. Environ. Med. 2001;11:241-7.

30. Chu D, Wong WL, Mavligit GM. Immunotherapy with Chinese medical herbs I. Immune restoration of local xenogenic graft-versushost reaction in cancer patients by fractionated astragalus membranaceous invitro. J. Clin. Lab. Immunol. 1988;25:119.

31. Schmidt BL. PCR in laboratory diagnosis of human Borrelia burgdorferi infections. Clin. Microbiol. Rev. 1997;10:185-201.

32. Vojdani A, Raxlen BT. Simultaneous measurement of antibodies against Borrelia, Babesia and Ehrlichia by Western Blot and multipeptide ELISA. FASEB J. 2005;19:95, Abstract.

33. Vojdani A. Part 1: In vivo-induced antigen technology: the most sensitive method of detection for Lyme disease and other tick-borne diseases. Townsend Letter 2007;285:107-13.

34. Vojdani A. Part 2: The use of lymphocyte proliferation assay and cytokine production in seronegative patients with Lyme arthritis or neuroborreliosis. Townsend Letter 2007;286:104-11.

35. Rauter C, Mueller M, Diterich I, Zeller S, Hassler D, Meegans T, et al. Critical evaluation of urine-based PCR assay for diagnosis of Lyme borreliosis. Clin. Diag. Lab. Immunol. 2005;12:910-7.

36. Centers for Disease Control and Prevention. Recommendation for test performance and interpretation from the Second National Conference on Serologic Diagnosis of Lyme Disease. Morb. Mortal Wkly. Rep. 1995;44:590.

37. Luger SW, Krauss E. Serologic tests for Lyme disease: interlaboratory variability. Arch. Intern. Med. 1990;150:761-816.

38. Dressler F, Whalen JA, Reinhardt BN, Steere AC. Western blotting in the serodiagnosis of Lyme disease. J. Infect. Dis. 1993;167:392-400.

39. Engstrom SM, Shoop E, Johnson RC. Immunoblot interpretation criteria for serodiagnosis of early Lyme disease. J. Clin. Microbiol. 1995;33:419-27. 
40. Saah AJ, Hoover DR. "Sensitivity" and "specificity" reconsidered: the meaning of these terms in analytical and diagnostic settings. Ann. Intern. Med. 1997;126:91-4.

41. Mahan MJ, Slauch JM, Mekalanos JJ. Selection of bacterial virulence genes that are specifically induced in host tissues. Science 1993;259:686-8.

42. Mahan MJ, Heithoff DM, Sinsheimer RL, Low DA. Assessment of bacterial pathogenesis by analysis of gene expression in the host. Annu. Rev. Genet. 2000;34:139-64.

43. Rollins SM, Peppercorn A, Hang L, Hillman JD, Calderwood SB, Handfield $\mathrm{M}$, et al. In vivo induced antigen technology (IVIAT). Cellular Microbiol. 2005;7:1-9.

44. Sung SY, McDowell JV, Marconi RT. Evidence for the contribution of point mutations to VlsE variation and for apparent constraints on the net accumulation of sequence changes in VlsE during infection with Lyme disease spirochetes. J. Bacteriol. 2001;168:5855-61.

45. McDowell JV, Sung S, Hu LT. Evidence that the variable regions of the central domain of VlsE are antigenic during infection with Lyme disease spirochetes infection and immunity. Infect. Immun. 2002;70:4196-203.

46. Magnarelli LA, Ijdo JW, Padula SJ, Flavell RA, Fikrig E. Serologic diagnosis if Lyme borreliosis by using enzyme-linked immunosorbent assays with recombinant antigens. J. Clin. Microbiol. 2000;38:1735-9.

47. Alitalo A, Meri T, Lankinen H, Seppala I, Lahdenne P, Hefty PS, et al. Complement inhibitor factor $\mathrm{H}$ binding to Lyme disease spirochetes is mediated by inducible expression of multiple plasmid encoded outer surface protein $\mathrm{E}$ paralogs. J. Irnmunol. 2002; 169:3847-53.

48. Metts MS, McDowell JV, Theisen M, Hansen PR, Marconi RT. Analysis of the OspE determinants involved in binding of Factor $\mathrm{H}$ and OspE targeting antibodies elicited during Borrelia burgdorferi infection in mice. Infect. Immun. 2003;71:3587-96.

49. Crowley C, Huber BT. Host-adapted Borrelia burgdorferi in mice expresses OspA during inflammation. Infect. Immun. 2005;71:4003-10.

50. Gross DM, Forsthubert T, Tary-Lehmann M, Etling C, Ito K, Nagy ZA, et al. Identification of LFA-1 candidate autoantigen in treatment resistant Lyme arthritis. Science 1998;281:703-5.

51. Earnhart CG, Buckles EL, Dumler JS, Marconi RT. Demonstration of OspC type diversity in invasive human Lyme disease isolates and identification of previously uncharacterized epitope that defines the specificity of the OspC murine antibody response. Infect. Immun. 2005; 73:7869-77.

52. Earnhart CG, Marconi RT. OspC phylogenetic analyses support the feasibility of a broadly protective polyvalent chimeric Lyme disease vaccine. Clin. Vaccine Immunol. 2007;14:628-34.

53. Fingerle V, Goettner G, Gern L, Wilske B, Schulte-Spechtel U. Complementation of a Borrelia afzelii OspC mutant highlights the crucial role of OspC for dissemination of Borrelia afzelii in Ixodes ricinus. Int. J. Med. Microbiol. 2007;297:97-107.

54. Xu Q, McShan K, Liang FT. Identification of an OspC operator critical for immune evasion of Borrelia burgdorferi. Mol. Microbiol. 2007;64:220-31.

55. Xu Q, Seemanapali SV, McShan K, Liang FT. Constitutive espression of outer surface protein $\mathrm{C}$ diminishes the ability of Borrelia burgdorferi to evade specific humoral immunity. Infect. Immun. 2006;74:5177-84.

56. Metts MS, McDowell JV, Theisen M, Hansen PR, Marconi RT. Analysis of the OspE determinants involved in binding of factor $\mathrm{H}$ and OspE-targeting antibodies elicited during Borrelia burgdorferi infection in mice. Infect. Immun. 2003;71:3587-96.

57. Crother TR, Champion CI, Whitelegg JP, Aguilera R, Wu XY, Blanco DR, et al. Temporal analysis of the antigenic composition of Borrelia burgdorferi during infection in rabbit skin. Inf. Immun 2004;72:5063-5072.

58. Philipp MT, Wormser GP, Marques AR, Bitker S, Martin DS, Nowakowski $\mathrm{J}$, et al. A decline in $\mathrm{C} 6$ antibody titers occurs in successfully treated patients with culture-confirmed early localized or early disseminated Lyme borreliosis. Clin. Diag. Lab. Immunol. 2005; 12:1069-74.

59. Wallich R, Pattathu J, Kitiratschky V, Brenner C, Zipfel PF, Brade $\mathrm{V}$, et al. Identification and functional characterization of complement regulator-acquiring surface protein-1 of the Lyme disease spirochete Borrelia afzelii and Borrelia garinii. Infect. Immun. 2005:73:2351-9.

60. Haupt K, Kraiczy P, Wallich R, Brade V, Skerka C, Zipfel PF. Binding of human factor H-related protein 1 to serum-resistant Borrelia burgdorferi is mediated by Borrelial complement regulatoracquiring surface proteins. J. Infect. Dis. 2007;196:59-61.

61. Kraiczy P, Rossman E, Brade V, Simon MM, Skerka C, Zipfel PF, et al. Bidning of human complement regulators FHL-1 and factor $\mathrm{H}$ to CRASP-1 orthologs of Borrelia burgdorferi. Wien. Klin. Wochenschr. 2006;118:669-76.

62. Hanson MS, Cassat DR, Quo BP, Patel NK, McCarthy MP, Dorward DW, et al. Active and passive immunity against Borrelia burgdorferi decorin binding protein A (DbpA) protects against infection. Infect. Immun. 1998;6:2143-53.

63. Leuba-Garcia S, Martinez R, Gem L. Expression of outer surface proteins A and C of Borrelia afzelii in Ixodes ricinus ticks and in the skin of mice. Zentbl. Bakteriol. 1998;287:475-84.

64. Schwan TG, Piesman J. Temporal changes in outer surface proteins $\mathrm{A}$ and $\mathrm{C}$ of the Lyme disease-associated spirochete, Borrelia burgdorferi, during the chain of infection in ticks and mice. J. Clin. Microbiol. 2000;38:382-8.

65. Heikkila T, Seppala I, Saxen H, Panelius J, Yrjänäinen H, Lahdenne P. Species specific serodiagnosis of Lyme arthritis and Neuroborreliosis due to Borrelia burgdorferi stricto, B. afzelii, B. gorinii by using Decorin binding protein A. J. Clin. Microbiol. 2002:40:453-60.

66. Salazar CA, Rothemich M, Drouin EE, Glickstein L, Steere AC. Human Lyme arthritis and the immunoglobulin G antibody response to the 37-kilodalton arthritis-related protein of Borrelia burgdorferi. Infect. Immun. 2005;73:2951-7.

67. Schmid GP. Epidemiology and clinical similarities of human spirochetal diseases. Rev. Infect. Dis. 1989;2:51460-9.

68. Guyard C, Chester ME, Raffel SJ, Schrumpf ME, Policastro PF, Porcella SF, et al. Relapsing fever spirochetes contain chromosomal genes with unique direct tandemly repeated sequences. Infect. Immun. 2005;73:3035-7.

69. Homer MJ, Lodes MJ, Reynolds LD, Zhang Y, Douglass JF, McNeill PD, et al. Identification and characterization of putative secreted antigens from Babesia microti. J. Clin. Microbiol. 2003;41:723-9.

70. Brown WC, McGuire TC, Zhu D, Lewin HA, Sosnow J, Palmer GH. Highly conserved regions of the immunodominant major surface protein 2 of the genogroup II Ehrlichial pathogen Anaplasma marginale are rich in naturally derived $\mathrm{CD} 4+\mathrm{T}$ lymphocyte epitopes that elicit strong responses. J. Immunol. 2001;166:1114-24.

71. Gilmore RD, Bellville TM, Sviat SL, France M. The Bartonella vinsonii subsp. arupensis immunodominant surface antigen BrpA gene, encoding a 382-kilodalton protein composed of repetitive sequence, is a member of a multigene family conserved among Bartonella species. Infect. Immun. 2005;73:3128-36.

72. Werner JA, Feng S, Kasten RW, Hodzec E, Chomel BB, Barthold SW. Cloning, characterization and expression of Bartonella henselaeP26. Clin. Vaccine. Immunol. 2006;13:830-6.

73. Rawlins ML, Gerstner C, Hill HR, Litwin CM. Evaluation of a western blot method for detection of Yersinia antibodies: evidence of serological cross-reactivity between Yersinia outer membrane proteins and Borrelia burgdorferi. Clin. Diag. Lab. Immunol. 2005; 12:1269-74.

74. Bruckbauer HR, Preac-Mursic V, Fuchs R, Wilske B. Crossreactive proteins of Borrelia burgdorferi. Eur. J. Clin. Microbiol. Infect. Dis. 1992;11:224-32.

75. Sobieszczanska B, Prozondo-Mordanska A. Cross-reactivity between Borrelia burgdorferi and arthrogenic bacteria in sera from patients with reactive arthritis. Rocz. Akad. Med. Bialmyst. 1996;41:90-95.

76. Grogan JL, Kramer A, Nogai A, Dong L, Ohde M, SchneiderMergener J, et al. Cross-reactivity of myelin basic protein-specific T-cells with multiple microbial peptides: Experimental autoimmune encephalomyelitis induction in TCR transgenic mice. J. Immunol. 1999;163:3764-70.

77. Vojdani A, Campbell AW, Anyanwu E, Kashanian A, Bock K, Vojdani E. Antibodies to neuron-specific antigens in children with autism: possible cross-reaction with encephalitogenic proteins 
from milk. Chlamydia pneumoniae and Streptococcus group A. J. Neuroimmunol. 2002;129:168-77.

78. Vojdani A, Vojdani E, Cooper EL. Antibodies to myelin basic protein, myelin oligodendrocytes peptides, $\alpha-\beta$-crystallin, lymphocyte activation and cytokine production in patients with multiple sclerosis. J. Internal Med. 2003;254:363-74.

79. Greunewald R, Ropper AH, Lior H. Serologic evidence of Campylobacter jejuni coli enteritis in patients with Guillain-Barre syndrome. Arch. Neurol. 1991;48:1080-2.

80. Benvenga S, Guarneri F, Vaccaro M, Santarpia L, Trimarchi F. Homologies between proteins of Borrelia burgdorferi and thyroid autoantigens. Thyroid 2004;14:964-6.

81. Ghosh S, Seward R, Costello CE, Stollar BD, Huber BT. Autoantibodies from synovial lesions in chronic, antibiotic treatment-resistant Lyme arthritis bind cytokeratin-10. J. Immunol. 2006;177:2486-94.

82. Hu LT, Perides G, Noring R, Klempner MS. Binding of human plasminogen to Borrelia burgdorferi. Infect. Immun 1995;63:3491-6.

83. Ahrens D, Koch AE, Pope RM, Stein.Picarella M, Niedbala MJ. Expression of matrix metalloproteinase 9 (96-kd gelatinase B) in human rheumatoid arthritis. Arthritis Rheum. 1996;39:1576-87.

84. Behera AK, Hilderbrand E, Scagliotti J, Steere AC, Hu LT. Induction of host matrix metalloproteinases by Borrelia burgdorferi differs in human and murine Lyme arthritis. Infect. Immun. 2005;73:126-34.

85. Halperin JJ, Volkman DJ, Wu P. Central nervous system abnormalities in Lyme neuroborreliosis. Neurology 1991;41:1571.

86. Schmutzhard E, Pohl P, Stanek P. Borrelia burgdorferi antibodies in patients with relapsing-remitting form and chronic progressive form of multiple sclerosis. J. Neurol. Neurosur. Psychiatry 1988;51:1215.

87. Garcia-Monco JC, Villar BF, Alen JC, Benach JL. Borrelia burgdorferi in the central nervous system: experimental and clinical evidence for early invasion. J. Infect. Dis. 1990;161:1187-93.
88. Kim KS. Pathogenesis of bacterial meningitis from bacteraemia to neuronal injury. Nat. Rev. Neurosci. 2004;4:376-85.

89. Coleman JL, Benach JL. The urokinase receptor can be induced by Borrelia burgdorferi through receptor of the innate immune system. Infect. Immun. 2003:71:5556-64.

90. Grab DJ, Perides G, Dumler JS, Kim KJ, Park J, Kim YV, et al. Borrelia burgdorferi, host-derived proteases and the blood-brain barrier. Infect. Immun. 2005;73:1014-22.

91. Alarcon-Chaidez F, Ryan R, Wikel S, Dardick K, Lawler C, Foppa IM, et al. Confirmation of tick bite by detection of antibody to Ixodes calreticulin salivary protein. Clin. Vaccine Immunol. 2006;13:1217-22.

92. Garg R, Juncadella IJ, Ramamoorthi N, Ananthnarayanan SK, Thomas V, Rincon M, et al. Cutting edge: CD4 is the receptor for the tick saliva immunosuppressor, Salp15. J. Immunol. 2006;177:6579-83.

93. Alaedini A, Latov N. Antibodies against OspA epitopes of Borrelia burgdorferi cross-react with neural tissue. J. Neuroimmunol. 2005;159:192-5.

94. Riberiro JMC, Alarcon-chaidez F, Francischetti IMB, Mans B, Mather TN, Valenzuela JG, et al. An annotated catalog of salivary gland transcripts from Ixodes scapularis ticks. Insect Biochem. Mol. Biol. 2006;36:111-29.

95. Hsu HC, Wu Y, Yang P, Wu Q, Job G, Chen J, et al. Overexpression of activation-induced cytidine deaminase in B cells is associated with production of highly pathogenic autoantibodies. J. Immunol. 2007:178:5357-65.

96. Yurasov S, Wardemann H, Hammersen J, Tsuiji M, Meffre E, Pascual V, et al. Defective B cell tolerance checkpoints in systemic lupus erythematosus. J. Exp. Med. 2005;201:703-11.

97. Notkins AL. New predictors of disease. Scientific American 2007;296:72-9.

Received May 16, 2007; accepted August 15, 2007 


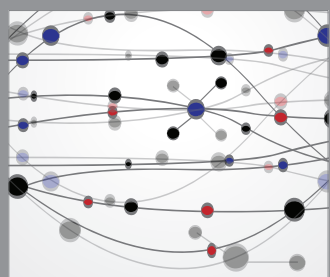

The Scientific World Journal
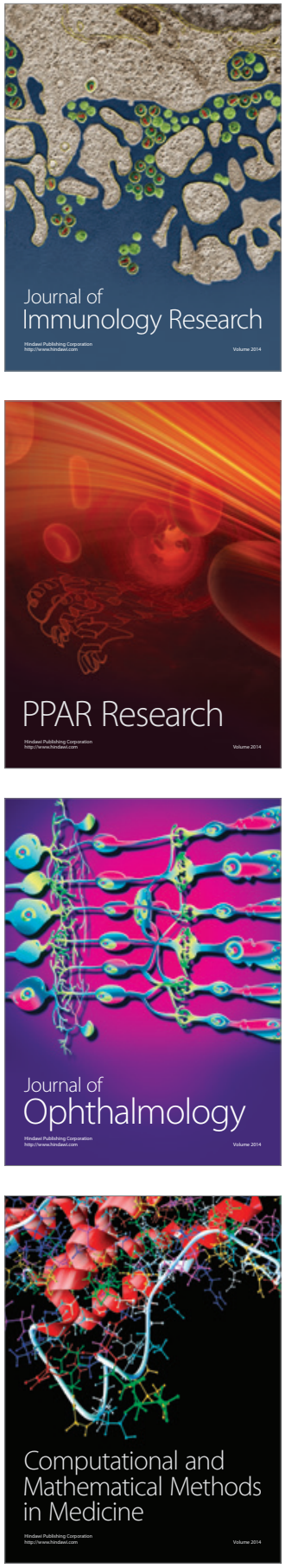

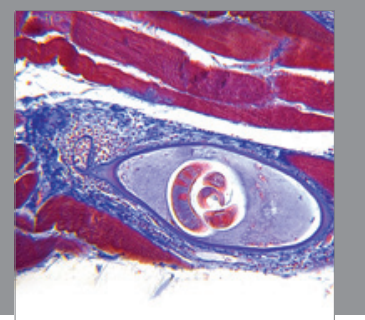

Gastroenterology

Research and Practice
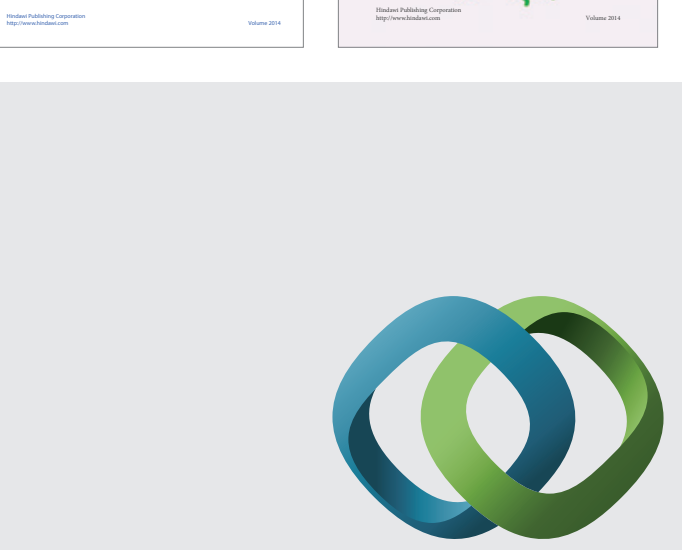

\section{Hindawi}

Submit your manuscripts at

http://www.hindawi.com
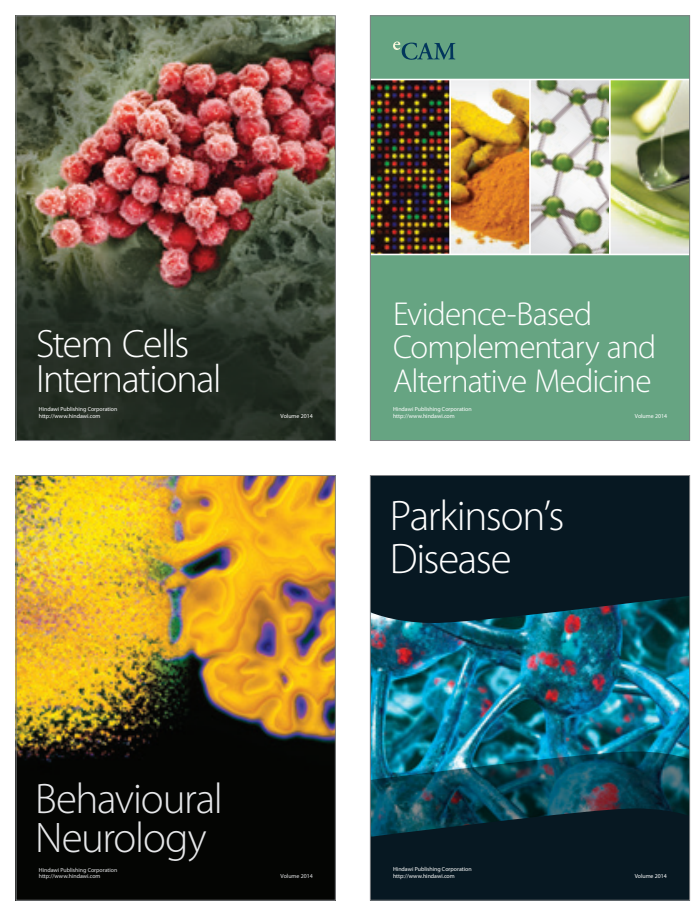

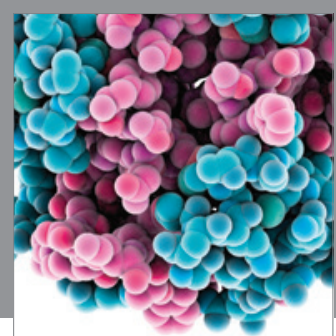

Journal of
Diabetes Research

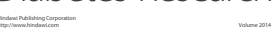

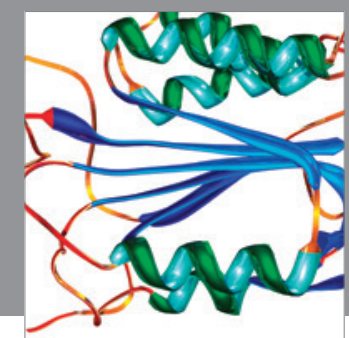

Disease Markers
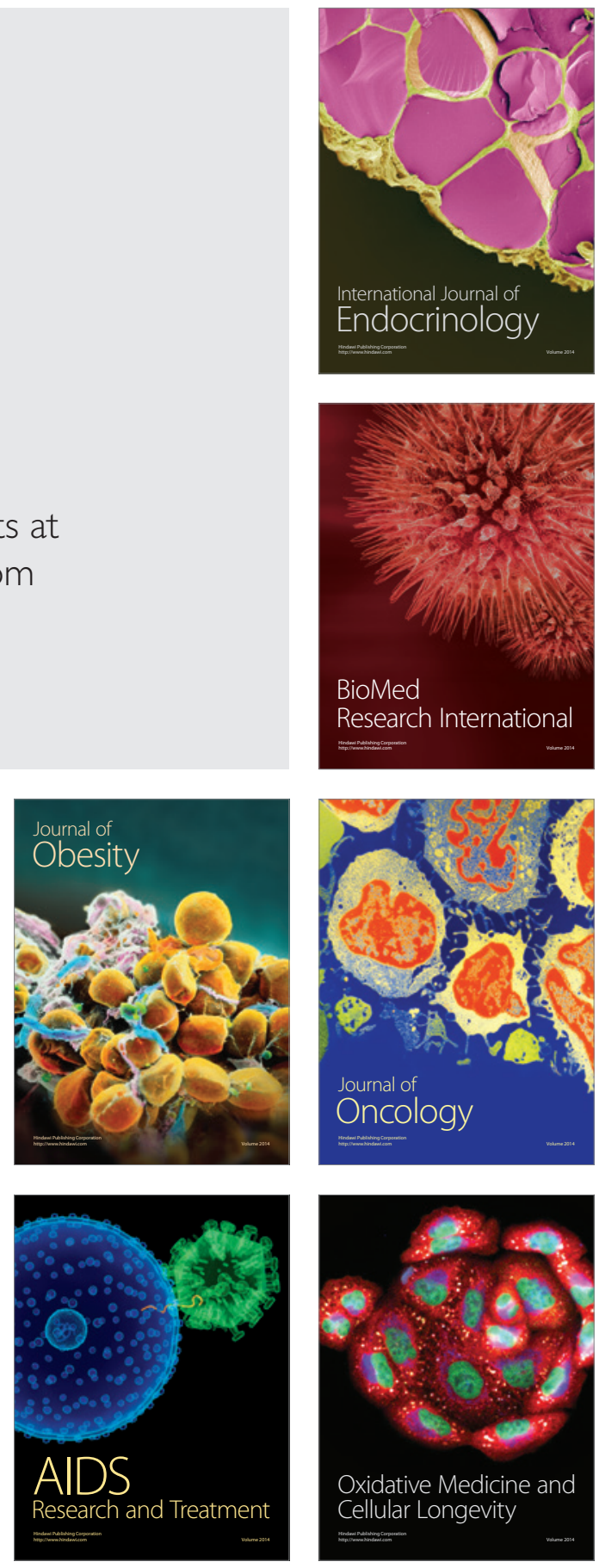